\title{
Studi Evaluatif Pada Pelaksanaan Kurikulum BK 2013 di Kota Tegal (Studi tentang Pelaksanaan Kurikulum 2013 Pada MGBKKota Tegal dalam Hal Perencanaan, Pelaksanaan dan Evaluasi Kurikulum 2013)
}

\author{
Suriswo, Maufur, Fikri Aulia \\ 1) Dosen Bimbingan dan Konseling FKIP UPS Tegal
}

Program Studi Bimbingan dan Konseling

FKIP - Universitas Pancasakti Tegal

\begin{abstract}
Abstrak
Tujuan khusus dari penelitian ini adalah mengevaluasi tentang Pelaksanaan Kurikulum 2013 pada MGBK Kota Tegal dalam Hal Perencanaan, Pelaksanaan dan Evaluasi Kurikulum 2013. Pada setiap kurikulum, evaluasi menjadi hal yang sangat penting untuk diperhatikan, mengingat evaluasi sebagai salah satu alat untuk menilai dan mengukur tingkat kemampuan peserta didik di samping memahami perubahan-perubahan yang terjadi pada keseharian siswa. Kurikulum 2013 mengisyaratkan penting sistem penilaian diri, dimana peserta didik dapat menilai kemampuannya sendiri. Sistem penilaian mengacu pada tiga (3) aspek penting, yakni: knowlidge, skill dan Attitude. Berdasarkan permasalahan di atas, peneliti tertarik untuk meneliti untuk Pelaksanaan Kurikulum 2013 oleh Guru BK SMP pada MGBK Kota Tegal dalam Hal Perencanaan, Pelaksanaan dan Evaluasi Kurikulum 2013. Desain kegiatan evaluasi program dalam bahasan ini menggunakan model CIPP dengan rancangan penelitian evaluasi kualitatif yang bersifat deskriptif, pendekatan dalam penelitian ini menggunakan pendekatan fenomenologik, yaitu memungkinkan untuk mengungkap realita yang mendeskripsikan situasi secara komprehensif dengan konteks yang sesungguhnya tentang efektifitas pelaksanaan kurikulum BK 2013 di Kota Tegal.
\end{abstract}

Kata Kunci : Manajemen Kurikulum, Kurikulum 2013

\begin{abstract}
The specific objective of this study was to evaluate the 2013 Curriculum Implementation in the Tegal City MGBK in terms of Planning, Implementation and Evaluation of the 2013 Curriculum. In each curriculum, evaluation became a very important thing to consider, considering evaluation as a tool for assessing and measuring ability levels students in addition to understanding the changes that occur in the daily lives of students. The 2013 curriculum implies an important self-assessment system, where students can assess their own abilities. The scoring system refers to three (3) important aspects, namely: knowlidge, skill and Attitude. Based on the above problems, researchers were interested in researching for the 2013 Curriculum Implementation by Junior High School Counseling Teachers in Tegal City MGBK in terms of Planning, Implementation and Evaluation of 2013 Curriculum. The design of program evaluation activities in this discussion used the CIPP model with descriptive qualitative evaluation research designs. The approach in this study uses a phenomenological approach, which allows to reveal the reality that describes the situation comprehensively in the real context of the effectiveness of the 2013 BK curriculum implementation in Tegal City.

Keywords: Curriculum Management, Curriculum 2013
\end{abstract}




\section{PENDAHULUAN}

Guru merupakan jabatan profesi yang semestinya memiliki berbagai kompetensi yang harus terus dikembangkan searah dengan perkembangan zaman. Kompetensi merupakan seperangkat pengetahuan, keterampilan, dan sikap yang ditampilkan melalui unjuk kerja yang harus dikuasai guru dalam rangka proses pendewasaan peserta didik. Sesuai Kep Mendiknas Nomor 045 Tahun 2002 menyebutkan bahwa kompetensi sebagai seperangkat tindakan cerdas dan penuh tanggung jawab dalam melaksanakan tugastugas sesuai dengan pekerjaan tertentu.

Guru sebagai pendidik profesional mempunyai tugas utama mendidik, mengajar, membimbing, mengarahkan, melatih, menilai, dan mengevaluasi peserta didik pada pendidikan anak usia dini jalur pendidikan formal, pendidikan dasar, dan pendidikan menengah. Selain tugas utamanya tersebut, guru juga dimungkinkan memiliki tugas-tugas lain yang relevan dengan fungsi sekolah/madrasah. Oleh karena itu, dalam penilaian kinerja guru beberapa subunsur yang perlu dinilai adalah Penilaian kinerja yang terkait dengan pelaksanaan proses pembelajaran bagi guru mata pelajaran atau guru kelas, meliputi kegiatan merencanakan dan melaksanakan pembelajaran, mengevaluasi dan menilai, menganalisis hasil penilaian, dan melaksanakan tindak lanjut hasil penilaian dalam menerapkan 4 (empat) domain kompetensi yang harus dimiliki oleh guru.

Proses pendidikan-pembelajaran tersebut membutuhkan sosok guru yang profesional yang sejahtera. Rujukan berpikirnya adalah Guru menempati posisi strategis yang tidak tergantikan walaupun perkembangan media pembelajaran maju demikian pesat. Karenanya, guru harus 1) memenuhi standar kualifikasi pendidikan, 2) menguasai kompetensi profesi keguruan, 3) memiliki komitmen yang tinggi terhadap profesi yang 4) diimbangi dengan upah/gaji/penghasilan yang layak untuk menghidupi diri dan keluarganya.

Pendidikan bermutu identik dengan pembelajaran bermutu, yaitu pembelajaran yang mampu memberi ruang sekaligus dorongan kepada peserta didik untuk berekspresi dan mengapresiasikan kebutuhan belajar sesuai bakat, minat selaras usia pertumbuhan-perkembangan serta kondisi lingkungan hidup peserta didik (geografis, demografi, kultur, sosial-ekonomi) sebagai bekal kehidupan pada zamannya kelak.

Kurikulum 2013 sebagai kurikulum yang yang baru memiliki arah dan paradigma yang berbeda dibandingkan kurikulum-kurikulum sebelumnya, yakni kurikulum Berbasis Kompetensi (KBK) tahun 2004 dan Kurikulum Tingkat Satuan Pendidikan (KTSP) tahun 2006. Dalam kurikulumum 2004 (KBK) sistem penilaian Selain itu kurikulum erat sekali kaitannya dengan teori pendidikan. Teori tentang kurikulum dijabarkan melalui teori pendidikan. Sukmadinata (dalam Sudrajat, 2008) mengemukakan empat teori pendidikan yang berhubungan dengan kurikulum, yaitu: (1) pendidikan klasik; (2) pendidikan pribadi; (3) teknologi pendidikan dan (4) teori pendidikan interaksional. Setiap kurikulum akan mencerminkan teori pendidikan yang digunakan. Pada teori-teori pendidikan itu, evaluasi tetap menjadi hal penting dibicarakan.

Pada setiap kurikulum, evaluasi menjadi hal yang sangat penting untuk diperhatikan, mengingat evaluasi sebagai salah satu alat untuk menilai dan mengukur tingkat kemampuan peserta didik di samping memahami perubahan-perubahan yang terjadi pada keseharian siswa. Kurikulum 2013 mengisyaratkan penting sistem penilaian diri, dimana peserta didik dapat menilai kemampuannya sendiri. Sistem penilaian mengacu pada tiga (3) aspek penting, yakni: knowlidge, skill dan Attitude.Tujuan khusus dari penelitian ini adalah mengevaluasi tentang Pelaksanaan Kurikulum 2013 pada MGBK Kota Tegal dalam Hal Perencanaan, Pelaksanaan dan Evaluasi Kurikulum 2013.

\section{METODE}

Desain kegiatan evaluasi program dalam bahasan ini menggunakan model CIPP dengan rancangan penelitian evaluasi kualitatif yang bersifat deskriptif, pendekatan dalam penelitian ini menggunakan pendekatan fenomenologik, yaitu memungkinkan untuk mengungkap realita yang mendeskripsikan situasi secara komprehensif dengan konteks yang sesungguhnya tentang efektifitas pelaksanaan kurikulum BK 
2013 di Kota Tegal. Keputusan-keputusan yang diambil dari penilaian implementasi pada setiap tahapan evaluasi program diklasifikasikan dalam tiga katagori yaitu rendah, menengah, dan tinggi.

Evaluasi program kurikulum BK 2013 di Kota Tegal menggunakan Model CIPP yang dikembangkan oleh Stufflebeam, dkk pada tahun 1967 di Ohio State University yang dikutip Suharsimi Arikunto, dan Cepi Syafruddin Abduljabar (2008 : 45), CIPP merupakan sebuah singkatan dari huruf awal empat kata yaitu: Context evaluation, Input evaluation, Process evaluation dan Product evaluation.Jadi CIPP sebagai metode evaluasi memandang program yang dievaluasi sebagai sebuah sistem, maka CIPP akan menganalisis program tersebut berdasarkan komponen-komponen context, input, process dan product.

\section{HASIL}

Dalam hasil penelitian akan dibahas beberapa temuan yang akan dipaparkan dalam langka-langkah CIPP (context, Input, Process dan Product)

A. Evaluasi Context

Program bimbingan dan konseling di Sekolah Menengah Pertama disusun berdasarkan kebutuhan peserta didik/konseli dan kebutuhan sekolah. Berdasarkan Peraturan Menteri Pendidikan dan Kebudayaan No. 111 Tahun 2014 tentang Bimbingan dan Konseling pada Pendidikan Dasar dan Pendidikan Menengah, struktur program bimbingan dan konseling terdiri atas rasional, visi dan misi, deskripsi kebutuhan, tujuan, komponen program, bidang layanan, rencana operasional (action plan), pengembangan tema/topik, rencana evaluasi, pelaporan dan tindak lanjut, dan anggaran biaya. Struktur program bimbingan dan konseling merupakan komponen-komponen yang harus ada namun bukan sebagai sebuah tahapan.

Dalam perencanaan program bimbingan dan konseling, terdapat dua tahapan, yaitu (1) tahap persiapan (preparing) dan (2) tahap perancangan (designing). Tahap persiapan (preparing) terdiri dari (1) melakukan asesmen kebutuhan, (2) aktivitas mendapatkan dukungan unsur lingkungan sekolah, dan (3) menetapkan dasar perencanaan. Tahap perancangan (designing) terdiri atas (1) menyusun program tahunan, dan (2) menyusun program semesteran.

A. Tahap Persiapan (Preparing) dalam Perencanaan Program

Tahap persiapan (preparing) terdiri atas kegiatan melakukan asesmen kebutuhan, mendapatkan dukungan pimpinan dan staf sekolah, menetapkan dasar perencanaan layanan bimbingan dan konseling.

1. Melakukan asesmen kebutuhan

Asesmen kebutuhan merupakan kegiatan yang bertujuan untuk menemukan kondisi nyata peserta didik yang akan dijadikan dasar dalam merencanakan program bimbingan dan konseling. Langkahlangkah asesmen meliputi :

a. Mengidentifikasi data yang dibutuhkan untuk penyusunan program layanan. Langkah awal dalam asesmen kebutuhan adalah menentukan data yang akan diukur/diungkap untuk kepentingan penyusunan program layanan bimbingan dan konseling. Data yang perlu diungkap antara lain yaitu data tentang tugastugas perkembangan, permasalahan dan prestasi peserta didik/konseli.

b. Memilih instrumen pengumpulan data sesuai kebutuhan Instrumen pengumpulan data yang dapat digunakan dalam asesmen kebutuhan, di antaranya (1) instrumen dengan pendekatan masalah, seperti Alat Ungkap Masalah Umum (AUM-U), Alat Ungkap Masalah Belajar : Prasyarat, Keterampilan, Sikap Diri dan Lingkungan (AUM-PTSDL), Daftar Cek Masalah (DCM), (2) instrument dengan pendekatan SKKPD yaitu Inventori Tugas Perkembangan (ITP), (3) instrumen dengan pendekatan tujuan bidang layanan (pribadi, sosial, belajar dan karir), dapat berupa angket, pedoman observasi, pedoman wawancara, dan angket sosiometri. Instrumen-instrumen tersebut dapat dipilih sesuai dengan kebutuhan kegiatan perencanaan program bimbingan dan konseling.

c. Mengumpulkan, Mengolah, Menganalisis, dan Menginterpretasi Data Hasil Asesmen Kebutuhan. Pengumpulan data dilakukan dengan menggunakan instrumen yang dipilih. Pengumpulan, pengolahan, analisis dan interpretasi hasil analisis data dilakukan sesuai dengan manual. Setiap instrumen pengumpul data yang telah standar memiliki manual. Bila instrumen yang digunakan belum standar maka pengolahan,analisis, dan interpretasi hasil analisis data menggunakan manual yang disusun sendiri. 
2. Mendapatkan dukungan kepala dan komite sekolah

Berdasarkan hasil asesmen kebutuhan peserta didik/konseli, guru bimbingan dan konseling atau konselor mencari dukungan dari berbagai pihak seperti kepala sekolah, wakil kepala sekolah, wali kelas, guru kelas, komite sekolah, dan kepala tata usaha untuk keterlaksanaan program bimbingan dan konseling di sekolah. Upaya untuk mendapatkan dukungan dapat dilakukan dengan beberapa cara misalnya konsultasi, rapat koordinasi, sosialisasi, dan persuasi. Kegiatan ini dapat dilakukan sebelum menyusun program maupun selama penyelenggaraan program bimbingan dan konseling. Hasil konsultasi, rapat koordinasi, sosialisasi, dan persuasi tergambar pada kebijakan yang mendukung terselenggaranya program, fasilitas untuk pelaksanaan program, kolaborasi dan sinergitas kerja dalam penyelenggaraan program bimbingan dan konseling.

\section{Menetapkan dasar perencanaan program}

Perencanaan program bimbingan dan konseling didasarkan pada landasan filosofis dan teoretis bimbingan dan konseling. Landasan ini berisi keyakinan filosofis dan teoritis, misalnya bahwa semua peserta didik/konseli itu unik dan harus dilayani dengan penuh perhatian; setiap peserta didik/konseli dapat meraih keberhasilan, untuk mencapai keberhasilan dibutuhkan upaya kolaboratif; program bimbingan dan konseling merupakan bagian integral dari proses pendidikan; program bimbingan dan konseling dimaksudkan untuk memenuhi kebutuhan-kebutuhan setiap peserta didik/konseli. Selain mendasarkan pada landasan filosofis dan teoretis, perencanaan layanan bimbingan dan konseling juga harus didasarkan pada kebutuhan peserta didik/konseli. Landasan filosofis, landasan teoritis dan hasil asesmen kebutuhan dipaparkan secara ringkas dalam rasional program bimbingan dan konseling.

B. Evaluasi Input

Pada evaluasi Input, terdiri dari tahap Perancangan (Designing) dalam Perencanaan Program. Tahap perancangan (designing) terdiri dari dua (2) kegiatan, yaitu penyusunan program tahunan, dan penyusunan program semesteran. Setiap kegiatan diuraikan pada bagian berikut.

1. Penyusunan Program Tahunan Bimbingan dan Konseling

Struktur program tahunan bimbingan dan konseling terdiri atas: a) rasional, b) dasar hukum, c) visi dan misi, d) deskripsi kebutuhan, e) tujuan, f) komponen program, g) bidang layanan, h) rencana operasional, i) pengembangan tema/topik, j) rencana evaluasi, pelaporan dan tindak lanjut, dan k) anggaran biaya, dan 1) sarana prasarana. Masing-masing diuraikan sebagai berikut.

\section{a. Merumuskan rasional}

Uraian dalam rasional merupakan latar belakang yang melandasi program bimbingan dan konseling yang akan diselenggarakan. Beberapa aspek yang perlu diuraikan dalam rasional meliputi : 1) urgensi layanan bimbingan dan konseling di Sekolah Menengah Atas; 2) kondisi objektif di sekolah masingmasing berupa permasalahan, hambatan, kebutuhan, budaya sekolah sekaligus potensi-potensi keunggulan yang dimiliki oleh peserta didik; 3) kondisi objektif yang ada di lingkungan masyarakat yang menunjukkan daya dukung lingkungan dan ancamanancaman yang mungkin berpengaruh terhadap perkembangan peserta didik/konseli; dan 4) harapan yang ingin dicapai dari layanan bimbingan dan konseling.

\section{b. Menentukan Dasar Hukum}

Dasar hukum yang ditentukan menjadi landasan kebijakan guru bimbingan dan konseling atau konselor dalam melaksanakan tugas dan fungsinya di satuan pendidikan. Penulisan dasar hukum mengikuti kaidah urutan dari perundangan tertinggi yang relevan sampai aturan yang ditetapkan oleh satuan pendidikan, misalnya: undang-undang, peraturan pemerintah, peraturan menteri, peraturan daerah, surat keputusan kepala sekolah.

c. Merumuskan visi dan misi

Rumusan visi dan misi bimbingan dan konseling harus sesuai dengan visi dan misi sekolah. Oleh karena itu, sebelum menetapkan visi dan misi program layanan bimbingan dan konseling, perlu terlebih dahulu menelaah visi dan misi sekolah. Oleh karena itu, sebelum menetapkan visi dan misi program layanan bimbingan dan konseling, perlu terlebih dahulu menelaah visi dan misi sekolah, selanjutnya merumuskan visi dan misi program layanan bimbingan dan konseling.

d. Mendeskripsikan Kebutuhan 
Rumusan deskripsi kebutuhan diidentifikasi berdasarkan asumsi tentang tugas perkembangan yang seharusnya dicapai peserta didik/konseli dan asesmen kebutuhan yang telah dilakukan pada tahap sebelumnya. Hasil asesmen inilah yang selanjutnya menjadi deskripsi kebutuhan yang akan difasilitasi dalam pencapaian tujuan layanan yang akan diberikan. Berikut ini adalah contoh deskripsi kebutuhan berdasarkan hasil asesmen.

e. Merumuskan Tujuan

Rumusan tujuan dibuat berdasarkan deskripsi kebutuhan peserta didik/konseli. Rumusan tujuan yang akan dicapai disusun dalam bentuk perilaku yang harus dikuasai peserta didik/konseli setelah memperoleh layanan bimbingan dan konseling.

f. Menentukan Komponen Program

Komponen program bimbingan dan konseling, komponen program bimbingan dan konseling di SMP meliputi: (1) Layanan Dasar, (2) Layanan Peminatan dan Perencanaan Individual (3) Layanan Responsif, dan (4) Dukungan sistem. Berikut penjelasan mengenai masing-masing komponen.

g. Mengidentifikasi bidang layanan

Bimbingan dan konseling pada satuan pendidikan mencakup empat bidang layanan, yaitu bidang layanan yang memfasilitasi perkembangan pribadi, sosial, belajar, dan karir. Pada hakikatnya perkembangan tersebut merupakan satu kesatuan utuh yang tidak dapat dipisahkan dalam setiap diri individu peserta didik/konseli. Materi layanan bimbingan klasikal disajikan secara proporsional sesuai dengan hasil asesmen kebutuhan 4 (empat) bidang layanan.1) Bidang Pribadi2) Bidang Sosial3) Bidang Belajar4) Bidang Karir

h. Menyusun Rencana Kegiatan (Action Plan)

Dalam membantu guru bimbingan dan konseling atau konselor mencapai tujuan BK selama satu tahun diperlukan rencana operasional yang memberikan panduan untuk penyusunan program tahunan dan semesteran.

Rencana kegiatan (action plan) bimbingan dan konseling merupakan rencana detail yang menguraikan tindakan-tindakan yang diperlukan untuk mencapai tujuan yang didapat dari hasil asesmen terhadap kondisi peserta didik serta standar kompetensi kemandirian siswa.

i. $\quad$ Menyusun Anggaran Biaya Layanan Bimbingan dan Konseling

Pada perencanaan program Layanan Bimbingan dan konseling perlu direncanakan anggaran biaya yang diperlukan selama program tersebut dijalankan. Usulan dana yang dibutuhkan selama Layanan Bimbingan dan konseling agar terlihat rinciannya secara jelas dapat dilakukan sejalan dengan program bimbingan dan konseling secara keseluruhan.

C. Evaluasi Proses

Program bimbingan dan konseling (BK) merupakan isi dari keseluruhan organisasi BK di sekolah. Program itu perlu disusun dengan memperhatikan kondisi yang terdapat di lapangan.

Program bimbingan dan konseling diartikan seperangkat kegiatan bimbingan dan konseling yang dirancang secara terencana, terorganisasi, terkoordinasi selama periode waktu tertentu dan dilakukan secara kait mengait untuk mencapai tujuan.

Pengurus Besar IPBI (2001:2) mendefinisikan program bimbingan dan konseling sebagai satuan rencana keseluruhan kegiatan bimbingan dan konseling yang akan dilaksanakan pada periode waktu tertentu, seperti periode bulanan, semester, tahunan. Sedangkan menurut Wahyu Sumidjo (1999:9) yang dimaksud dengan program ialah rencana komprehensif yang memuat penggunaan sumber-sumber dalam pola yang terintegrasi serta urutan tindakan kegiatan yang dijadwalkan untuk mencapai tujuan yang telah ditetapkan. Program menggariskan apa, oleh siapa, bilamana dan dimana tindakan akan dilakukan.

Tujuan penyusunan program tidak lain agar kegiatan BK di sekolah dapat terlaksana dengan lancar, efektif dan efisien, serta hasil-hasilnya dapat dinilai. Tersusun dan terlaksananya program BK dengan baik akan lebih menjamin pencapaian tujuan kegiatan bimbingan dan konseling pada khususnya, tujuan sekolah pada umumnya, juga akan lebih menegakkan akuntabilitas BK di sekolah. Menurut Juntika (2002:85) tujuan penyusunan program bimbingan dan konseling adalah adanya kejelasan arah pelaksanaan program, adanya kemudahan mengontrol dan mengevaluasi kegiatan, dan terlaksananya program kegiatan secara lancar, efisien, dan efektif. 
Program bimbingan dan konseling tersebut hendaknya dibuat secara tertulis dan selanjutnya dikomunikasikan kepada sesama Guru BK/Konselor, sejawat dan guru, staf sekolah lainnya, serta pimpinan sekolah, untuk selanjutnya menjadi rambu-rambu bagi kerja sama antara Guru BK/Konselor dengan semua personil-personil sekolah yang dimaksudkan itu.

Program bimbingan dan konseling disusun dan dikembangkan didasarkan atas pertimbangan bahwa program yang disusun dengan baik akan memberikan banyak keuntungan, baik bagi peserta didik yang mendapat layanan bimbingan dan konseling maupun bagi petugas yang menyelenggarakan. Di samping itu program bimbingan dan konseling yang baik, memungkinkan keberhasilan suatu layanan bimbingan dan konseling.

Rochman Natawidjaja (1984) menjelaskan bahwa program bimbingan yang direncanakan dengan baik dan terinci, akan memberikan banyak keuntungan. Keuntungan-keuntungan tersebut adalah (1) memungkinkan para petugas bimbingan menghemat waktu, usaha, biaya dengan menghindarkan kesalahan-kesalahan dan usaha coba-coba yang tidak menguntungkan; (2) memungkinkan siswa untuk mendapatkan pelayanan bimbingan secara seimbang dan menyeluruh, baik dalam kesempatan ataupun dalam jenis pelayanan bimbingan yang diperlukan; (3) memungkinkan setiap petugas mengetahui dan memahami peranannya dan mengetahui bagaimana dan dimana mereka harus melakukan upaya secara tepat; (4) memungkinkan para petugas untuk menghayati pengalaman yang berguna untuk kemajuan sendiri dan untuk kepentingan para siswa yang dibimbingnya.

Dalam penyusunan program bimbingan dan konseling diharapkan memenuhi unsur-unsur dan persyaratan tertentu. Menurut Prayitno (1998) unsur-unsur yang harus diperhatikan dan menjadi isi program bimbingan dan konseling meliputi : kebutuhan siswa, jumlah siswa yang dibimbing, kegiatan di dalam dan di luar jam belajar sekolah, jenis bidang bimbingan dan jenis layanan, volume kegiatan BK, dan frekuensi layanan terhadap siswa.

Sedangkan syarat-syarat yang harus dipenuhi dalam penyusunan program bimbingan dan konseling adalah sebagai berikut:

a. Berdasarkan kebutuhan bagi pengembangan peserta didik sesuai dengan kondisi pribadinya, serta jenjang dan jenis pendidikannya.

b. Lengkap dan menyeluruh, artinya memuat segenap fungsi bimbingan. Kelengkapan program ini disesuaikan dengan kebutuhan dan karakteristik peserta didik pada satuan pendidikan yang bersangkutan.

c. Sistematik, dalam arti program disusun menurut urutan logis, tersinkronisasi dengan menghindari tumpang tindih yang tidak perlu, serta dibagi-bagi secara logis.

d. Terbuka dan luwes, artinya mudah menerima masukan untuk pengembangan dan penyempurnaan, tanpa harus merombak program itu secara menyeluruh.

e. Memungkinkan kerja sama dengan fihak yang terkait dalam rangka sebesar-besarnya memanfaatkan berbagai sumber dan kemudahan yang tersedia bagi kelancaran dan keberhasilan pelayanan BK.

f. Memungkinkan diselenggarakannya penilaian dan tindak lanjut untuk penyempurnaan program pada khususnya dan peningkatan keefektifan dan keefisienan penyelenggaraan program BK pada umumnya.

D. Evaluasi Produk

Semua guru bimbingan dan konseling atau konselor harus membuat laporan penyelenggaraan bimbingan dan konseling sebagai bentuk akuntabilitas kinerja profesional. Pengakuan ekuivalensi kinerja profesional guru bimbingan dan konseling atau konselor yang ada dalam pada laporan merujuk kepada Tabel Perhitungan Ekuivalensi Kegiatan Layanan Bimbingan dan Konseling di Luar Kelas dengan Jam Kerja yang tercantum pada Permendikbud No.111tahun 2014 tentang Bimbingan dan Konseling pada Pendidikan Dasar dan Menengah.

Pelaporan merupakan langkah lanjutan setelah evaluasi. Isi dalam pelaporan lebih bersifat mendeskripsikan dan memberi uraian analisis terhadap hasil-hasil yang telah dicapai dalam kegiatan evaluasi sebelumnya. Pelaporan pada hakikatnya merupakan kegiatan menyusun dan mendeskripsikan seluruh hasil yang telah dicapai dalam evaluasi proses maupun hasil dalam format laporan yang dapat memberikan informasi kepada seluruh pihak yang terlibat tentang keberhasilan dan kekurangan dari program bimbingan dan konseling yang telah dilakukan. 
Terdapat tiga aspek pokok yang perlu diperhatikan dalam penyusunan laporan, yaitu; a) sistematika laporan hendaknya logis dan dapat dipahami, b) deskripsi laporan yang disusun hendaknya memperhatikan kaidah penulisan dan kebahasaan yang telah dibakukan, dan c) laporan pelaksanaan program bimbingan dan konseling harus dilaporkan secara akurat dan tepat waktu. Akurasi laporan yang dibuat menggambarkan detil keseluruhan layanan yang telah dilakukan. Bersifat tepat waktu berarti laporan harus diserahkan kepada pihak terlibat dan berkepentingan sesuai dengan waktu yang telah disepakati bersama. Tujuan yang diharapkan dari pelaporan pelaksanaan program bimbingan dan konseling ini adalah:

a. Memberikan informasi perkembangan kemajuan, dinamika permasalahan dan keunggulan, serta capaian akhir program bimbingan dan konseling kepada seluruh pihak yang terlibat dan berkepentingan

b. Menyediakan mekanisme umpan balik bagi pihak yang terlibat dan berkepentingan terhadap program bimbingan dan konseling dalam rangka modifikasi dan pengembangan

c. Memberikan jaminan akuntabilitas kepada publik bahwa program bimbingan dan konseling yang telah dilaksanakan dan dievaluasi telah memenuhi prinsip program yang efektif, efisien, dan berkualitas.

3. Langkah-langkah Penyusunan Laporan

Langkah-langkah penyusunan laporan pelaksanaan program bimbingan dan konseling dibagi dalam tiga tahap, yaitu persiapan, pengumpulan dan penyajian data, dan penulisan laporan.

a. Tahap Persiapan

Pada tahap ini, guru bimbingan dan konseling atau konselor hendaknya melakukan identifikasi terlebih dahulu tentang berbagai hal yang terkait dengan kegiatan pelaporan. Beberapa diantaranya, seperti latar belakang kegiatan pelaporan, kegiatan layanan yang akan dilaporkan, sumber data yang iperlukan, tujuan yang diharapkan, dan batas akhir penyampaian laporan.

b. Pengumpulan dan Penyajian Data

Langkah berikutnya dalam penyusunan laporan pelaksanaan program bimbingan dan konseling adalah pengumpulan dan penyajian data. Data yang diperlukan adalah data-data dan informasi-informasi mengenai keterlaksanaan program bimbingan dan konseling, dan ketercapaian tujuan program bimbingan dan konseling. Setelah data dan informasi dikumpulkan, kemudian diidentifikasikan atau dikelompokkan. Hasil identifikasi atau pengelompokkan dideskripsikan dalam laporan pelaksanaan program bimbingan dan konseling.

c. Penulisan Laporan

Penulisan laporan pelaksanaan program bimbingan dan konseling harus mengacu pada sistematika yang telah ditetapkan sehingga laporan tersebut dapat tersaji secara runtut dan mudah dipahami.

Istilah tindak lanjut dalam evaluasi program bimbingan dan konseling dapat diklasifikasikan menjadi 2 (dua), yaitu tindak lanjut sebagai bagian utuh dari pelaksanaan layanan bimbingan dan konseling dan tindak lanjut sebagai tahap akhir dari kegiatan evaluasi. istilah tindak lanjut dalam pelaksanaan layanan dapat dimunculkan sebagai bentuk respon cepat terhadap refleksi yang dilakukan oleh guru bimbingan dan konseling atau konselor atas permasalahan-permasalahan yang teridentifikasi selama proses pemberian layanan. Adapun tindak lanjut yang akan diuraikan pada bagian ini adalah tindak lanjut sebagai bagian dari evaluasi program bimbingan dan konseling.

Tindak lanjut dalam kegiatan evaluasi merupakan kegiatan yang dilakukan untuk menindaklanjuti hasil pelaksanaan pelayanan bimbingan dan konseling. Berdasarkan data dan informasi yang diperoleh dari hasil evaluasi, guru bimbingan dan konseling atau konselor dapat memikirkan ulang keseluruhan program yang telah dilaksanakan dengan cara membuat desain ulang atau merevisi seluruh program atau beberapa bagian dari program yang dianggap belum begitu efektif. Jika hasil evaluasi secara keseluruhan disimpulkan baik, maka tindak lanjut dapat dilakukan dalam bentuk pengembangan atau peningkatan program menuju pencapaian tujuan dengan target yang lebih tinggi dan kompleks. Tindak lanjut pelaksanaan program bimbingan dan konseling akan menjadi alat penting untuk mengambil keputusan apakah program dilanjutkan, direvisi, atau dihentikan, meningkatkan program, serta digunakan untuk mendukung perubahanperubahan dalam sistem sekolah. 
Kegiatan tindak lanjut dilakukan berdasarkan temuan yang diperoleh dalam evaluasi program bimbingan dan konseling. Tindak lanjut tersebut dipergunakan oleh guru bimbingan dan konseling atau konselor untuk tujuan:

a. memperbaiki hal-hal yang masih lemah, kurang tepat atau kurang relevan dengan tujuan yang akan dicapai;

b. mengembangkan program dengan menambah atau merubah beberapa hal yang dapat meningkatkan kualitas pelayanan atau efektifitas program.

Kegiatan tindak lanjut dapat dilakukan melalui langkah-langkah berikut ini, yaitu:

a. menentukan aspek-aspek perbaikan atau peningkatan yang akan dilakukan. Perbaikan dan peningkatan sangat tergantung pada hasil evaluasi. Aspek-aspek dimaksud dapat mencakup; perbaikan/pengembangan terhadap standar perkembangan peserta didik, perbaikan/pengembangan layanan-layanan yang diberikan, dan perbaikan/ pengembangan isi materi dari layanan bimbingan dan konseling

b. menyusun ulang desain program secara umum atau layanan bimbingan dan konseling tertentu dalam rangka perbaikan atau pengembangan. Penyusunan ulang ini dapat dilakukan seperti ketika ,erencanakan program bimbingan dan konseling.

c. melaksanakan kegiatan tindak lanjut sesuai dengan aspek-aspek yang akan diperbaiki atau dikembangkan dan alokasi waktu yang telah ditentukan. Tindak lanjut yang dilakukan juga perlu memperhatikan pihak-pihak yang akan dilibatkan.

Keterlibatan pihak lain dapat memberikan jaminan kepercayaan yang tinggi bagi guru bimbingan dan konseling atau konselor bahwa program dan kegiatan layanan yang dilakukan telah dapat berfungsi sebagaimana mestinya.

\section{PEMBAHASAN}

Data hasil asesmen kebutuhan terhadap peserta didik/konseli digunakan untuk membuat profil individual, profil kelas, menyusun program tahunan dan semesteran, dan merencanakan pemberian layanan.

1. Membuat profil individual setiap peserta didik/konseli

Berdasarkan data hasil asesmen maka setiap peserta didik/konseli dapat disusun profil yang menggambarkan tentang identitas diri peserta didik, karakteristik tugas perkembangan, klasifikasi kecerdasan, bakat, minat, efikasi diri, motivasi belajar, kesiapan belajar, arah karir, kematangan sosial, kematangan emosi, manajemen konflik,regulasi diri dalam belajar, prestasi akademik dan non akademik yang dimiliki, latar belakang keluarga-sekolah-masyarakat dan lain-lain, serta gambaran tentang kelebihan dan kelemahan setiap peserta didik/konseli.

2. Membuat profil kelas

Berdasarkan data individual peserta didik/konseli tersebut, maka dikembangkan profil kelas, sehingga tiap kelas memiliki profilnya sendiri-sendiri. Profil sebaiknya dituangkan ke dalam bentuk matrik, misalnya dalam format landscape excel, atau dalam bentuk grafik sehingga semua data dapat dimasukkan. Dengan profil kelas ini dapat diketahui kedudukan peserta didik/konseli dalam kelas antara lain peta potensi kelas, dan sosiogram. Profil yang diperoleh akan menggambarkan variasi kebutuhan layanan bimbingan dan konseling yang meliputi: bimbingan dan konseling pribadi, sosial, belajar, dan karir.

3. Membuat program tahunan dan semesteran

Berdasarkan profil individual dan kelas, disusun rancangan program tahunan dan semesteran yang memuat komponen layanan (layanan dasar, layanan peminatan dan perencanaan individual, layanan responsif, dukungan sistem) dan bidang layanan bimbingan dan konseling (pribadi, sosial, belajar, karir).

4. Menyusun rancangan pemberian layanan bimbingan dan konseling

Berdasarkan profil individual dan kelas disusun rancangan pemberian layanan bimbingan dan konseling secara individual, kelompok, klasikal, kelas besar atau lintas kelas, dan atau menggunakan media. 


\section{SIMPULAN}

Guru bimbingan dan konseling atau konselor di SMP berperan membantu tercapainya perkembangan pribadi, sosial, belajar, dan karir peserta didik. Pada jenjang ini, guru bimbingan dan konseling atau konselor menjalankan semua fungsi bimbingan dan konseling yaitu fungsi pemahaman, fasilitasi, penyesuaian, penyaluran, adaptasi, pencegahan, perbaikan, advokasi, pengembangan, dan pemeliharaan. Meskipun guru bimbingan dan konseling atau konselor memegang peranan kunci dalam sistem bimbingan dan konseling di sekolah, dukungan dari kepala sekolah sangat dibutuhkan.

Sebagai penanggung jawab pendidikan di sekolah, kepala sekolah bertanggung jawab terhadap penyelenggaraan layanan bimbingan dan konseling. Selain itu, guru bimbingan dan konseling atau konselor harus berkolaborasi dengan pemangku kepentingan lain seperti guru mata pelajaran, wali kelas, komite sekolah, orang tua peserta didik, dan pihak-pihak lain yang relevan.

\section{SARAN}

Saran-saran yang dapat peneliti sampaikan sebagai bahan memajukan sekolah adalah sebagai berikut: 1) Bagi Pihak Lembaga, hasil penelitian terkait penerapan kurikulum 2013 sehingga berjalan lebih efektif. Namun Hendaknya perlu dilakukan upaya optimalisasi dari seluruh personel sekolah dalam pemahaman mengenai penerapan strategi self management sehingga disiplin belajar peserta didik dapat meningkat, 2) Bagi Kepala Sekolah, Kepala sekolah bekerjasama dengan guru pembimbing (guru BK) beserta seluruh aspek di sekolah guna meningkatkan layanan bimbingan dan konseling terkait dengan penerapan penerapan kurikulum 2013 dapat lebih memberi dampak positif pada peserta didik, 3) Bagi Guru Pembimbing (Guru BK), Guru pembimbing (guru BK) hendaknya memperhatikan dan meningkatkan program layanan bimbingan dan konseling di sekolah terkait disiplin belajar peserta didik, sehingga disiplin belajar peserta didik dapat ditingkatkan menjadi lebih baik lagi kedepannya.

\section{DAFTAR PUSTAKA}

Hasan, S.H. (1988). Evaluasi Kurikulum. Jakarta: P2LPTK Ditjen Dikti.

Ibrahim, R. (2007). Training Of Trainer (TOT) Implementasi KTSP Di Sekolah. Sekolah Pascasarjana Universitas Pendidikan Indonesia. Makalah.

Ibrahim, R. dan Nana Syaodih. (1996). Perencanaan Pengajaran. Jakarta: Rineka Cipta.

Idi, A. (1999). Pengembangan Kurikulum Teori dan Praktik. Jakarta: Gaya Media Pratama.

McDonald, (1965). Educational Models for Instruction. Washington DC: The Association for Supervision and Curriculum Development.

Mulyasa. E.(2013). Pengembangan dan Implementasi Kurikulum. Bandung: Remaja Rosdakarya.

Nasution, (1986). Didaktik Asas-Asas Mengajar. Bandung: CV. Jemars.

Sumantri, M. (1988). Kurikulum dan Pembelajaran. Jakarta: Departemen Pendidikan dan Kebudayaan Direktur Jenderal Pendidikan Tinggi Proyek Pengembangan Lembaga Pendidikan Tenaga Kependidikan.

Saylor, G.J et.al. (1981). Curriculum Planning for Better Teaching and Learning. New York: Holt Renehard and Winston. 
Tabrani, (2000). Upaya Meningkatkan Budaya Kinerja Guru Sekolah Dasar. Jakarta: PT. Nusantaralestari Ceriapratama.

Taba, Hilda. (1962). Curriculum Development: Theory and Practices. New York: Harcourt, Brace and World, Inc.

Undang-Undang Republik Indonesia No. 14 Tahun 2005 tentang Guru dan Dosen. Jakarta: Sinar Grafika. Usman, Uzer. (2007). Menjadi Guru Profesional. Bandung: Rosda.

Undang-Undang Republik Indonesia No. 20 Tahun 2003 tentang Sistem Pendidikan Nasional (Sisdiknas). Jakarta: Sinar Grafika.

Zais, R. (1976). Curriculum Principles and Foundation. New York: Harper and RowPublishers. 